\title{
Key elements for the Development of the Institutional, Operational and Image Components in a Strategic Public Transport System
}

\author{
Jonathan David Bernal', Carlos Alberto Moncada², and Diego Alexander Escobar ${ }^{3}$ \\ 'Subdirector de Transporte, Departamento Nacional de Planeación, Colombia; jonbernal@dnp.gov.co \\ 2Universidad Nacional de Colombia, Sede Bogotá, Departamento de Ingeniería Civil y Agrícola, Colombia; \\ camoncadaa@unal.edu.co \\ ${ }^{3}$ Universidad Nacional de Colombia, Sede Manizales, Departamento de Ingeniería Civil, Colombia; \\ daescobarga@unal.edu.co
}

\begin{abstract}
Objectives: This research proposes guidelines for the conceptual design and pre-operational stage of the Strategic Public Transport Systems, which are part of the National Urban Transport Policy in Colombia and which focus on the transformation of transit. Methods/Statistical Analysis: The early stage of operation of the Strategic Public Transport Systems will be emphasized because there are no practical guidelines to date that help understand and implement this type of transport system for Colombian cities that have between 250,000 and 600,000 inhabitants approximately. Specifically, the research makes a diagnosis based on secondary information obtained from the conceptual and detailed design of Transport System of Pasto, in order to propose technical guidelines for three major components: operational, institutional and image. Findings: The main weakness of the institutional component is identified in the fact that the National Government has not defined mechanisms to monitor and control traditional transportation systems. However, a monitoring committee was set up for the implementation of the new PNTP. It should be invested in the planning pyramid of the framework of business transformation. The proposed guidelines should be understood as a series of actions, decisions and conditions that seek to increase efficiency in the implementation of SETP. Application/Improvements: This is a document recommended for Mayors, managers of "management entities", transport and/or mobility secretaries, transporters, officials of the National Government and for future investigations that evaluate the impact on the rate associated with the guidelines proposed.
\end{abstract}

Keywords: Fleet, Guideline, Institutional Strengthening, SETP, Service Level, User Loyalty

\section{Introduction}

The implementation of the Strategic Public Transport Systems (SETP for its acronym in Spanish) in the so-called "Ciudades Amables" of the country has been a great challenge for the National Government. Specially due to the particular conditions of each region, as typical problems of urban environments arise each day ${ }^{1}$, such as little or no information to the user, motorcycle taxis, motorcycle rickshaws and bicycle taxis that associate with social problems, resistance to change on the part of the traditional transporters, noticeable decrease of the demand of Urban Public Transport (TPCU for its acronym in Spanish), motorcycles as main means of transport, etc 2 . These problems directly affect the operating conditions due to the

*Author for correspondence 


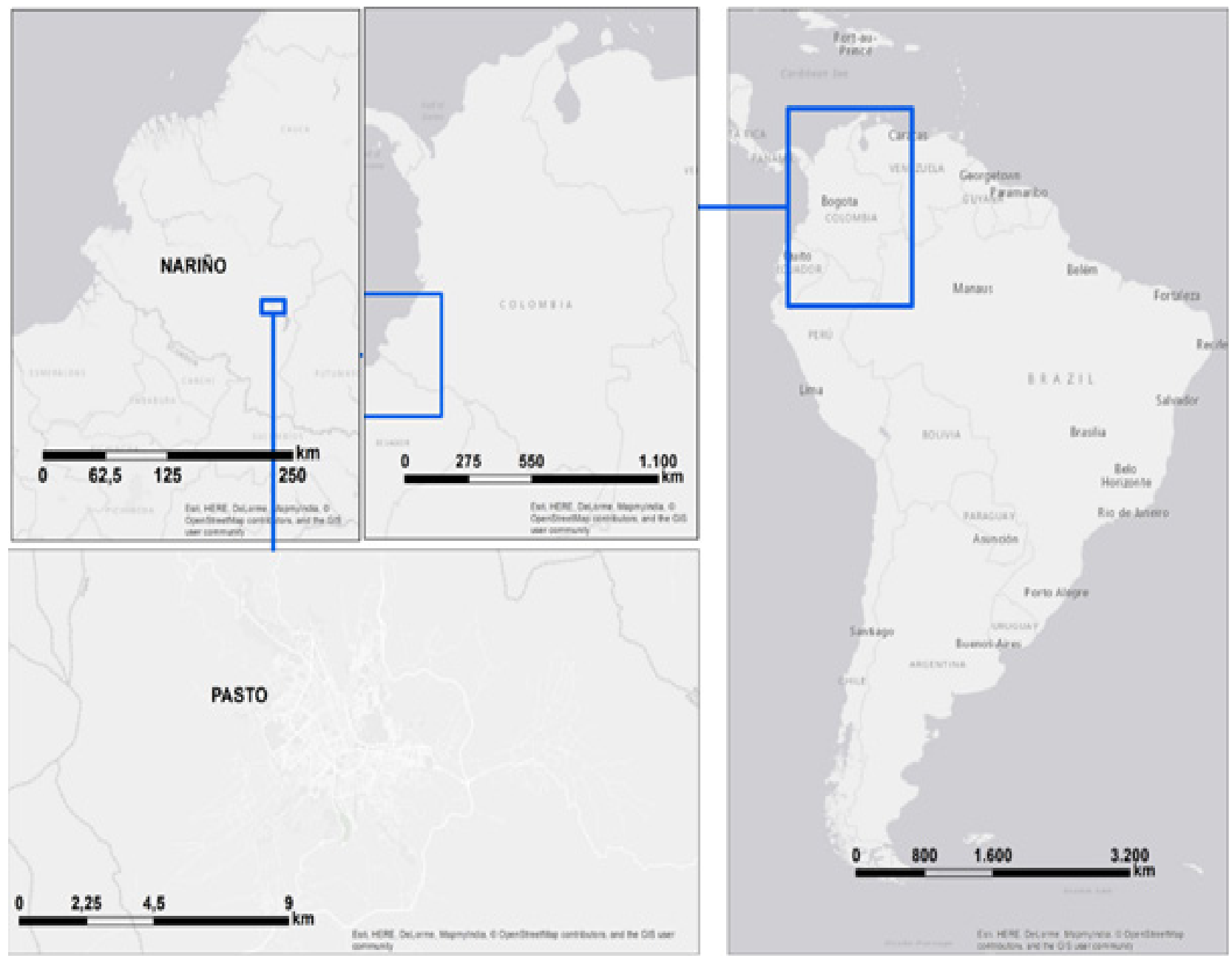

Figure 1. Geographical location of the municipality of Pasto.

wide difference in the estimation of the demand in the conceptual designs of the SETP, which hypothetically guarantee the self-sustainability in their operation ${ }^{3}$. This research article is based on the experiences of the National Government and specifically analyzes the implementation of the SETP in the municipality of Pasto, a city chosen as a case study given the conditions of progress and development of their transport system in operational terms. The main objective of the research is to propose guidelines in three components: 1. Institutional, 2. Operational, and 3. Image, in order to adjust the conceptual design and implementation of the pre-operational stage of the SETP.

The SETP were designed to cover $100 \%$ of the travel demand in transit, under parameters that respond to quality factors such as coverage, efficiency, accessibility and sustainability, as well as incorporating collection, fleet management and control, information technologies, service levels according to demand conditions and articulation with other means of transport $t^{4}$, unlike the Transmilenio in Bogota, Colombia. This new operational scheme reformulates the business structures of operators of traditional transport systems towards SETP, regulated by Decree 1079 of 2015, Article 2.2.1.2.2.2, which allows the operating companies of the regions to reorganize themselves in accordance with the conditions provided there or otherwise gives the power to the territorial entity to tender the operation of the routes, with the aim of complying with the minimum quality conditions.

The municipality of Pasto is the most important city in the south of Colombia and it is an obligatory route to 
travel to the Republic of Ecuador, to the region of upper Putumayo and to the south coast of the country, thus making it a focus point for the development of the entire southwestern region. Currently, the projected population for the year 2018 is 455,678 inhabitants out of which $83.7 \%$ (381,494 inhabitants) are located in the municipal seat and $16.3 \%(74,184$ inhabitants) are located in the rural area ${ }^{6}$. Approximately 600,000 trips are made daily in this city, out of which the largest percentage, approximately $40 \%$ of the trips, is carried out in non-motorized transport means. However, in 2006, approximately 184,000 daily travels in transit mode, while given the important number of users in this mean of transportation, the new system is projected to start recording some 124,000 travels per day, that is, $67 \%$ of what was mobilized more than a decade ago.

\section{Methodology}

The research methodology was centered upon the execution of four main stages in order to present clear guidelines for addressing the institutional, operational and image components in a SETP (Figure 2). The research

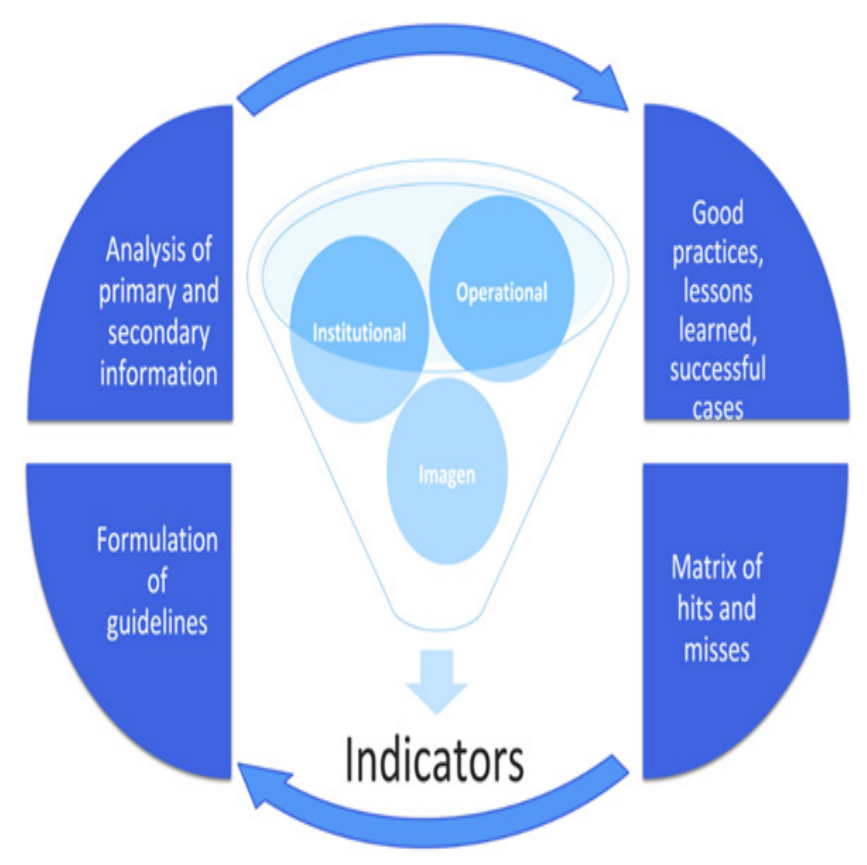

Figure 2. Methodological proposal. began by expanding the elements that, according to the authors, define and frame the National Urban Transport Policy (PNTP for its acronym in Spanish) in Colombia and defining the conditions under which the SETP and other transport systems work, based on what was formulated for the object of the case study, the city of Pasto, as part of the stage of primary and secondary information analysis. Subsequently, the study seeks to answer the question: What guidelines should be proposed to achieve the pre-operational stage in the SETP, optimizing the times of the start-up, taking into account the experience of the city of Pasto? The answering of this question is achieved by analyzing good practices, lessons learned and successful cases. Next, the current guidelines in institutional, operational and image terms for the SETP are analyzed in order to formulate and propose their adjustment based on the matrix of successes and failures obtained. The structure of the document allows to focus the results obtained in the following sections: 1 . Analysis of the implementation process of the SETP in the case study; 2. Analysis and proposal of the institutional component; 3 . Analysis and proposal of the operational component; and 4. Analysis and proposal of the image component.

\section{Results and Discussion}

\subsection{Analysis of the SETP Implementation Process in the Case Study}

The SETP are implemented in three major phases: 1. Preinvestment, 2. Construction, 3. Operation ${ }^{7}$, as presented in Figure 3.

In accordance with the Colombian principles of decentralization, as the authority of each of the territories, the territorial entities are responsible for the operation of transport; therefore, it is necessary for them to show an interest upon becoming part of the National Urban Transport Policy (PNTP for its acronym in Spanish) to the National Government. Once the territories make the decision to become part of the PNTP, Phase 1, Preinvestment, must begin. This phase has two components: the first is a technical component developed through the conceptual design of the SETP, while the second con- 


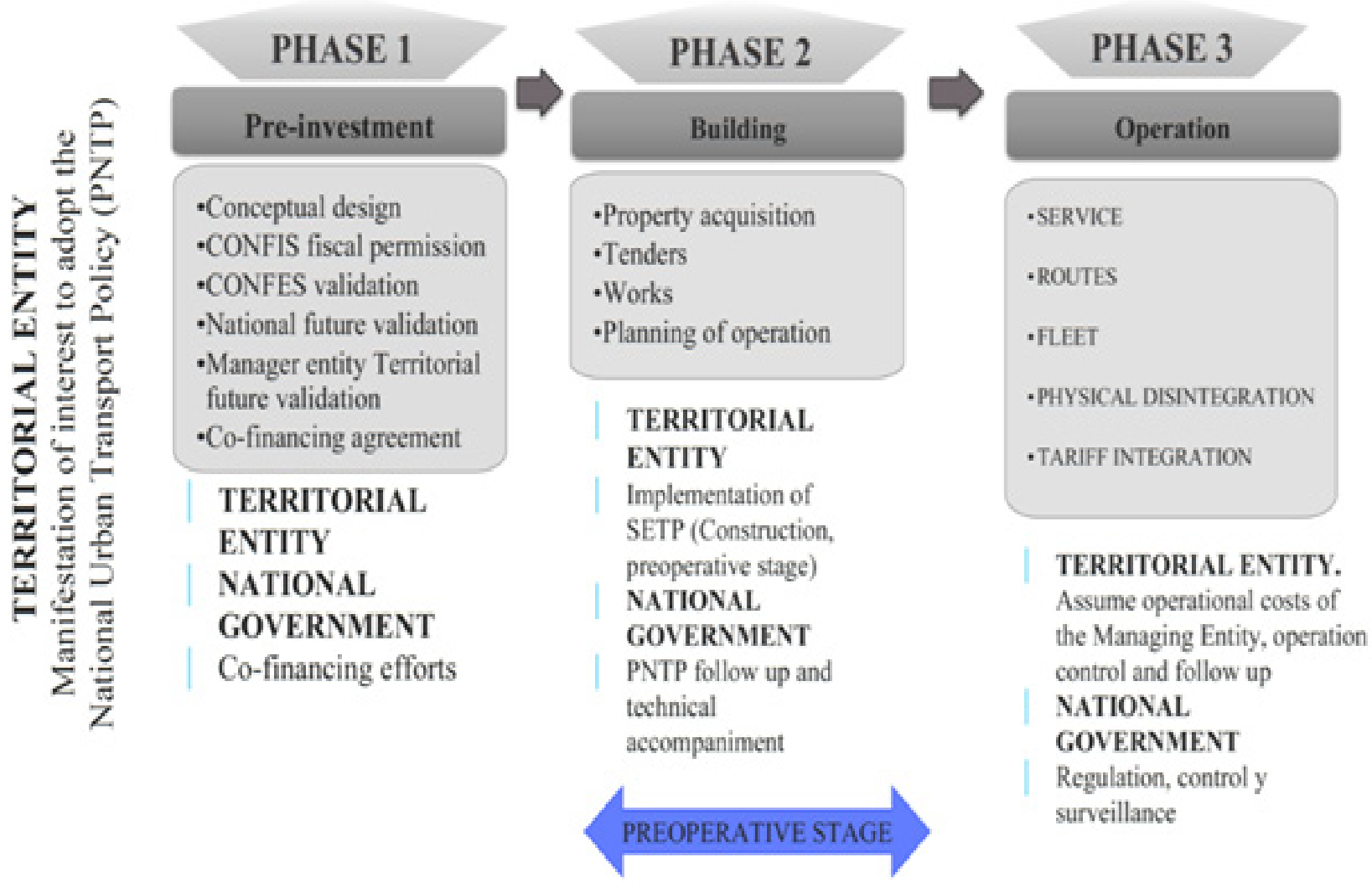

Figure 3. Phases of the implementation of the SETP.

sists of a political effort to achieve co-financing from the National Government. The technical document must reflect the infrastructure needs for the startof the SETP, under some operational components of the Transport System. This information finally reflects the contribution profile and defines the funding sources of the Nation and the territorial entity, until achieving a financial closure of the project. Once the sanity of the municipality's finances has been reviewed by the National Government, a fiscal endorsement is given to define the conditions of participation of the Nation and the disbursement schedule of the resources. Afterwards, the Ministry of Transport (MT) requests the National Council of Economic and Social Policy (CONPES for its acronym in Spanish) to declare the SETP project of national strategic importance, given that the budget commitments acquired exceed a period of National Government. Next, the future validity of the Nation is approved, for which the territorial entity must create the Managing Entity and guarantee the future validity on the part of the municipal council, as a necessary condition for the implementation of the SETP. Finally, the co-financing agreement is signed, which is a document equivalent to a contract that agrees to disbursements and other requirements.

Phase 2, Construction (See Figure 3), includes the planning of the operational component through two technical inputs: a) Conceptual design, and b) Detail structuring of the Transport System. In order to build the necessary infrastructure for the operation, it is necessary for the National Government and the territorial entity to provide the resources. These resources are executed through a bank fiduciary order administered by the managing entity in accordance with the parameters shown in Figure 4, which in the first instance is an infrastructure executing entity for the SETP, with a tendency to become an entity in charge of the planning and control 


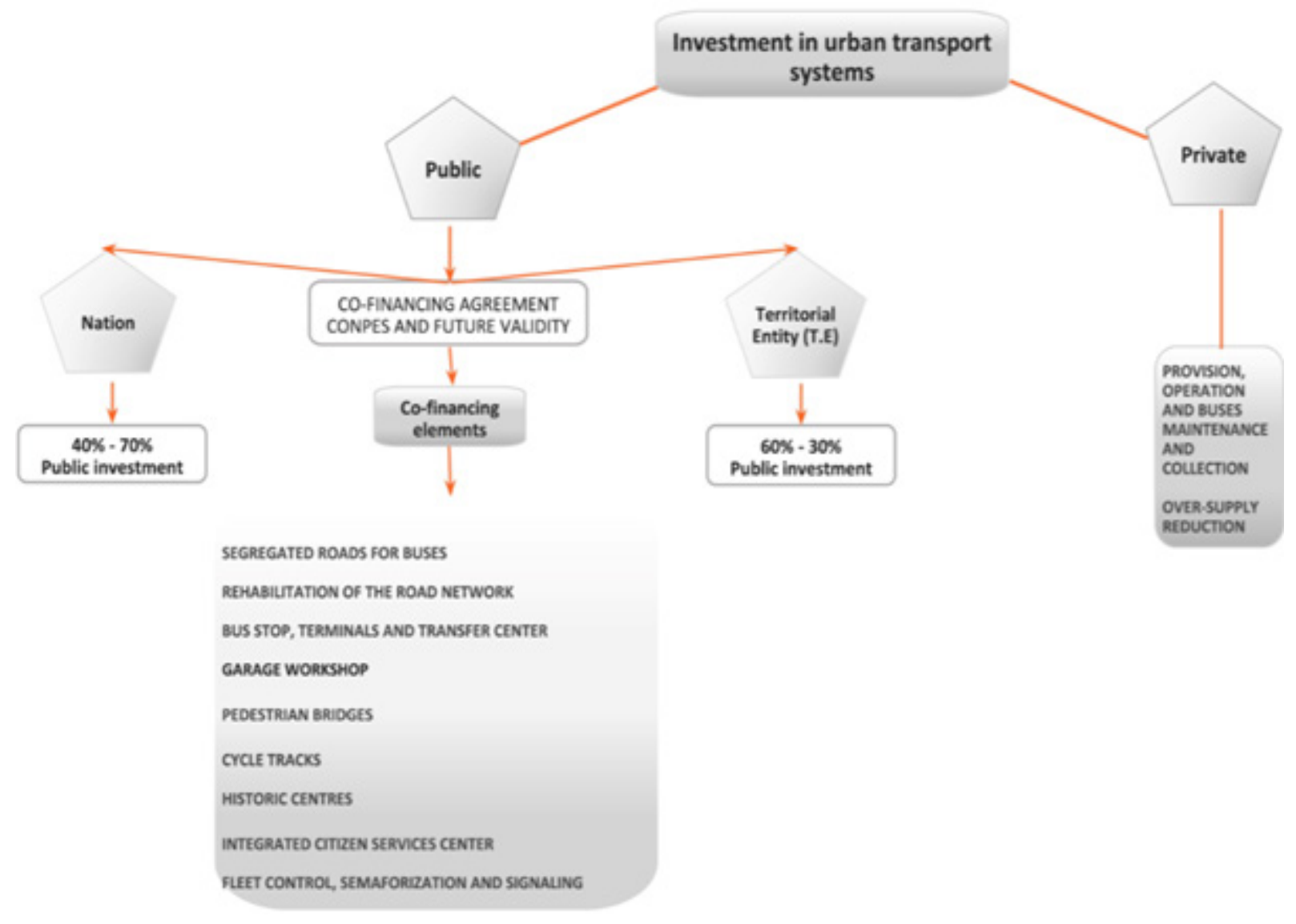

Figure 4. Finance structure of the SETP.

of the operation of the Transport System. Monitoring and sanctioning activities in the territory continue to be carried out by the territorial entity itself, since it continues to serve as the transport authority in it.

Phase 3. Operation (See Figure 3), will follow the conceptual design of routes or services defined in the conceptual design. This stage includes all the infrastructure elements that complement those required for the provision of the service such as terminals, stations, yards and workshops, as well as the form of its integration and the definition of the type of vehicle ${ }^{4}$. The territorial entity as a transport authority must support the due technical studies respecting the criteria of equity and proportionality of the companies in the market; likewise, when the transport companies fail to comply with the defined minimum service quality indicators, the operating permit will be lost and the respective bidding process for the new allocation of the route must begin.

For the specific case of the city of Pasto, 7 years passed since the demand of the National Policy to improve the urban public passenger transport service $e^{3}$ until the co-financing agreement was signed (See Figure 4). Subsequently, in 2015 the SETP was adopted through the signing of Decree 562. It is currently providing initial operation, where the learning curves in the implementation of this type of systems, the lack of forecasting of resources for networks of public services on the part of the territorial entities, the challenges that the territorial institutional capacity had to assume, the conditions of passenger demand and the interaction with the transporters, as well as other factors, have generated circumstances translated into delays in the execution schedules of the 
projects by the managing entity, causing a project structured to last four years (projected completion 2012) to be taking nine years. Due to the above, it is very important to have clear guidelines in operational, institutional and image terms, based on good practices, lessons learned and successful cases within the framework of the implementation of the PNTP.

\subsection{Analysis and Proposal of the Institutional Component}

The model that operates the SETP is that of free competition in the provision of services, based on an organization where the public sector maintains ownership of the infrastructure and private companies are responsible for operating the public passenger transport service ${ }^{8}$ under the influence of the territorial entity on the market structure based on a limited number of operating permits. One of the difficulties that a territorial entity encounters when implementing a SETP and launching the pre-operative stage consists of understanding the interaction that must be established with the entities of the National order. It is a fundamental objective to compile the necessary information to build a consultation tool for the management entities and the local administrations based on secondary information from national entities. Initially and in general terms, the operational design seeks to optimize the operation in the territory of organized transport systems, carrying out, among others, the elimination of overtravelling, reduction of routes of empty fleet, elimination of competition between routes, designing a unified service provision model focused on meeting the mobilization needs of the population. These designs result in lower emissions of Greenhouse Gases (GHG), reduction in accidents, generation and formalization of employment and a commitment by the National Government to intermediate cities to avoid large tenders that include demand and operational risks, such as the case of the Integrated Mass Transportation Systems in Colombia (Figure 5). The institutional scaffolding, which to date supports the implementation of the PNTP in Colombia, is as follows: 1. Ministry of Finance and Public Credit, 1 coordinator and 3 people to follow up on 16 Transport Systems, in

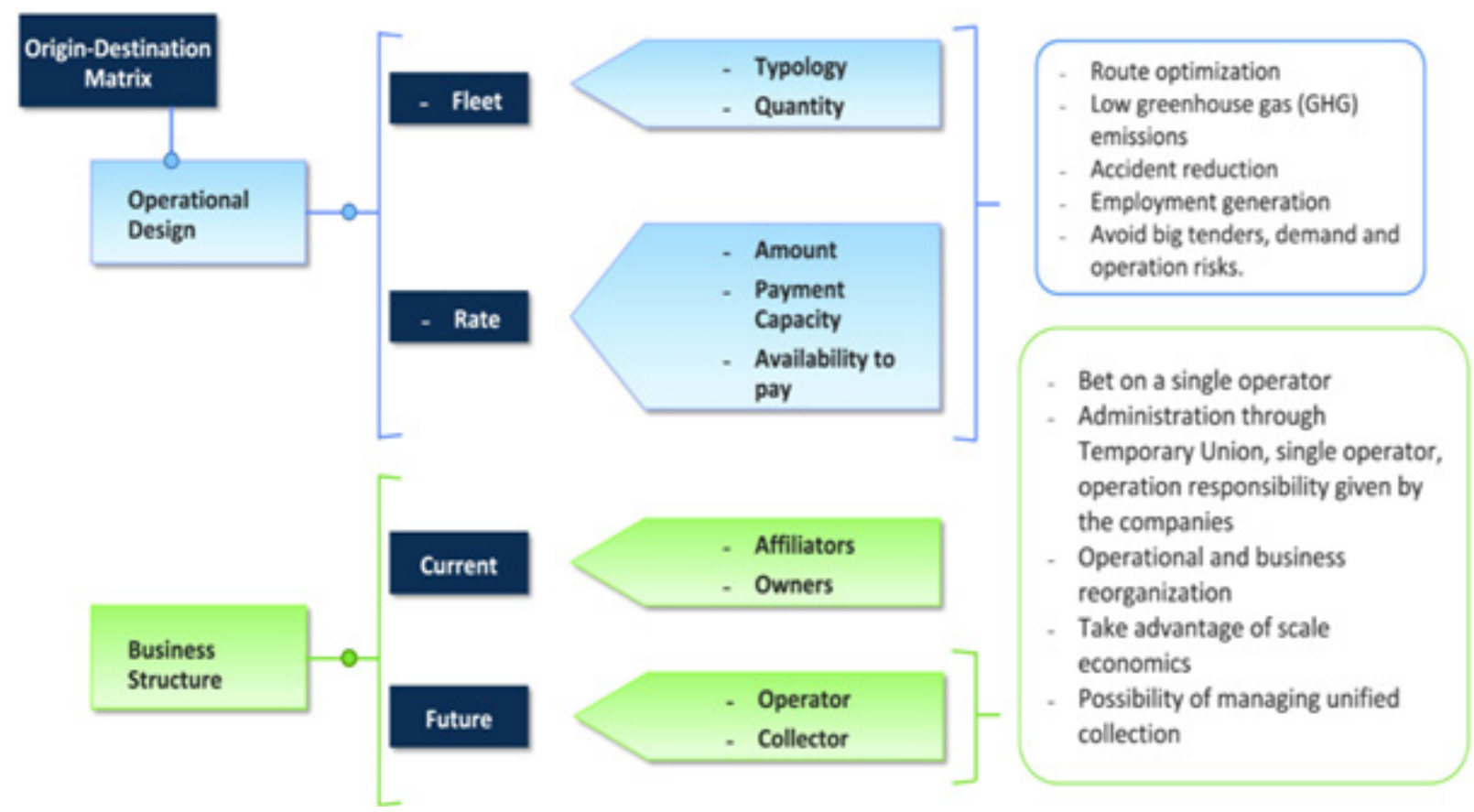

Figure 5. Institutional considerations of the SETP. 


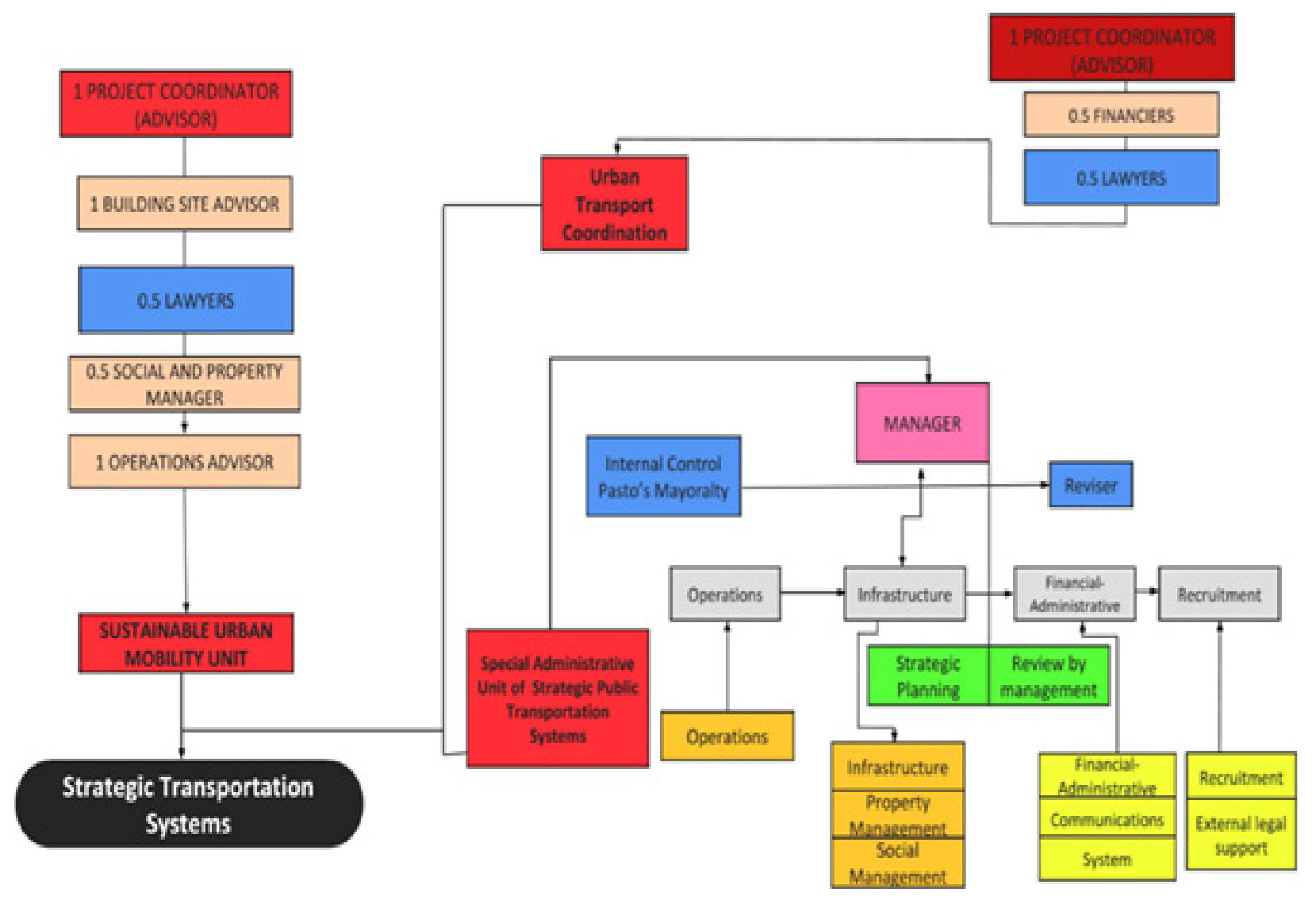

Figure 6. Organizational structure proposed to the interior of the National Government.

other words, a person reviews budget issues between 5 and 6 cities (SITM and SETP); 2. Ministry of Transport, 1 coordinator, 1 financier that contracts technical part of MHCP, and 23 interdisciplinary professionals that monitor the 16 cities; that is, around 1.5 cities per professional; 3. National Planning Department, 1 coordinator, 1 financial and 6 professionals in charge of monitoring the implementation of the Policy in 2 or 3 cities.

The burden of each one of the professionals is notable in each of the entities of the National Government since the territorial entities constantly require documents, information, suggestions, consultations and guidelines for the implementation of the SETP. The above evidences the need to strengthen the National Government work teams, which allow providing answers in a shorter time within the generation of efficiencies framework in the investments associated with the implementation of the PNTP, which in usual prices is estimated at 7.3 trillion pesos for the SITM and 1.4 trillion for the SETP. Table 1 shows the main institutional successes and failures identified in the territorial entities and the National Government in the process of implementing the SETP.

Based on the above, a personnel structure is proposed for the monitoring and formulation of policies for each of the SETP cities, since for constant prices of 2017, a team is required within the National Government (Figure 6) with an approximate cost of USD 2.5 million during the duration of the project (5 years). That is to say, if the SETP of Pasto would have an approximate cost of USD 140 million for 2017 constants, the investment in the personnel structure would only be an additional $2 \%$, under the hypothesis that this investment would guarantee an operation programme according to the goals of the Nation, 


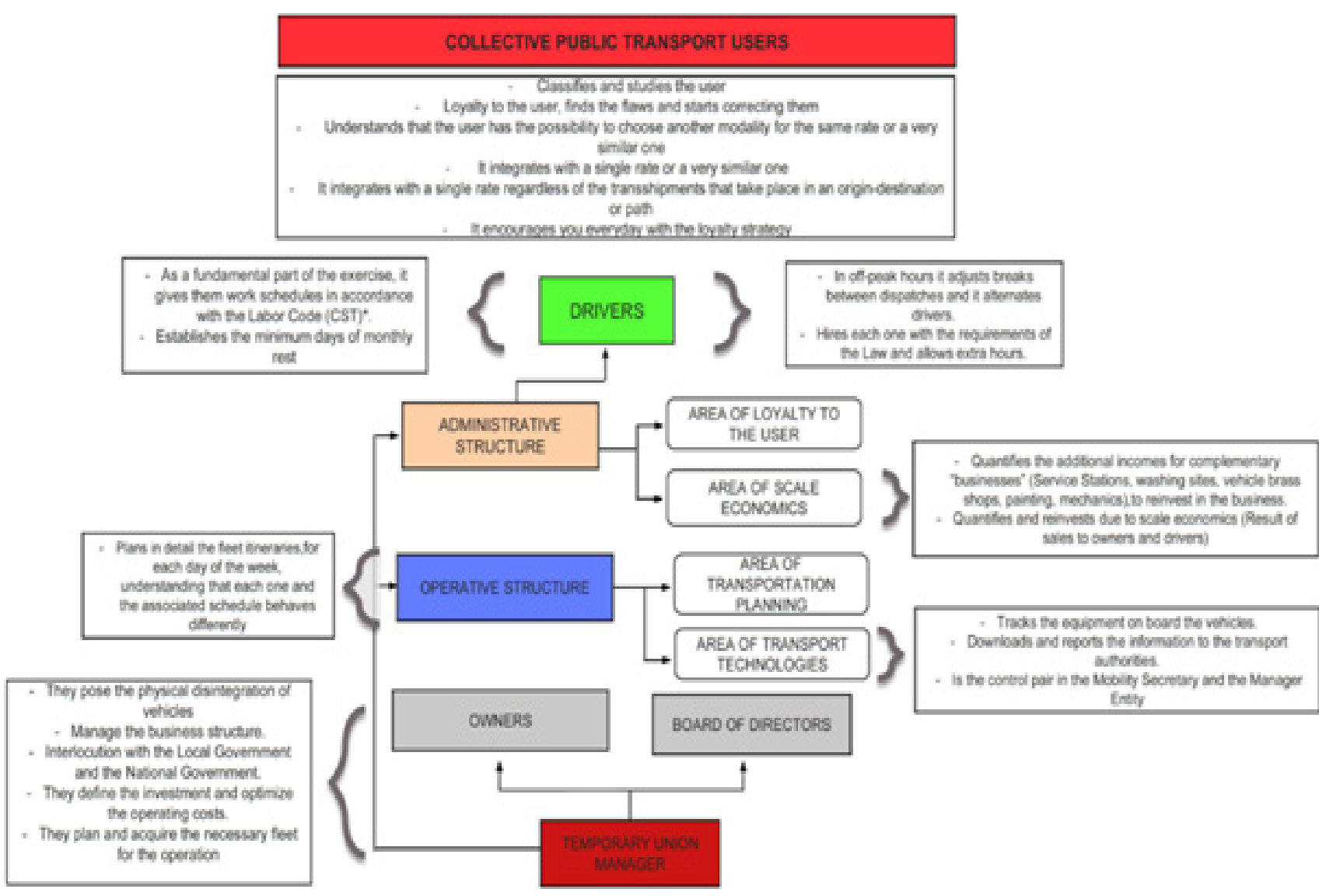

Figure 7. Organizational proposal of the TPC-SETP of Pasto pre-operative phase.

which is half of the time that the implementation and start-up of the SETP has taken.

However, the public sector should not only be transformed to achieve the objectives associated with the mobility of the municipality. The private sector must adapt to the conditions of the new operational scheme proposed by the PNTP, because they currently have a user who perceives the inefficiencies of the system and has the possibility to choose the way to satisfy their trip. In this sense, and with the purpose of achieving a transformation in favor of the user, an organizational structure is proposed for the transport company to adopt (Figure 7), reversing the hierarchy of business planning. What stands out most of this proposal is that this structure will allow prioritizing the user in each of the corporate decisions that are taken within the business agglomeration.
Additionally, four business areas are introduced: area of loyalty, area of economies of scale, area in charge of identifying and reinvesting the additional values captured by the transport operation, area of transport operation, and finally, area of transport technologies.

\subsection{Analysis and Proposals about the Operational Component}

Table 2 shows what are considered successes and failures of the National Government and the territorial entity in relation to the operational component, based on the diagnosis obtained in the city of Pasto.

Part of the objectives is to establish a series of procedures carried out in transport modeling software, which allows obtaining calibrated models that contribute to the operational component by optimizing a planned transition from the pre-operative phase based on the current 
Table 1. Successes and failures related to the institutional components

\begin{tabular}{|c|c|}
\hline Successes & Failures \\
\hline $\begin{array}{l}\text { The National Government identifies } \\
\text { an institutional weakness that does not } \\
\text { allow monitoring and controlling tradi- } \\
\text { tional transportation systems. } \\
\text { - The perverse incentives to the opera- } \\
\text { tor of the Traditional Transportation } \\
\text { Systems are identified, which consisted } \\
\text { of a collection by the companies to be } \\
\text { part of a "club", transferring the full } \\
\text { responsibility of the provision of the } \\
\text { service to the driver, generating the } \\
\text { "War of the penny" } \\
\text { A monitoring committee is set up to } \\
\text { implement the PNTP, made up of the } \\
\text { MT, DNP and MHCP. } \\
\text { Once the territorial entities are part of } \\
\text { the PNTP, they constitute for the first } \\
\text { time in their history an institution that } \\
\text { thinks exclusively about the implemen- } \\
\text { tation of a SETP, called the Transport } \\
\text { System Management Entity. } \\
\text { When observing the institutional } \\
\text { strengthening that is acquired from the } \\
\text { National Government and the Local } \\
\text { Government, the transportation oper- } \\
\text { ating companies are unified and create } \\
\text { a single company responsible for the } \\
\text { operation of the transport of the city. } \\
\text { organized transport solutions tran- } \\
\text { scend the mobility of a city. Additional } \\
\text { benefits are generated in terms of con- } \\
\text { gestion, accidents and pollution. }\end{array}$ & $\begin{array}{l}\text { - Inadequate National Government } \\
\text { teams are constituted, in terms of what } \\
\text { the territorial entities demand. } \\
\text { It was considered that the territorial } \\
\text { entities would have a greater capac- } \\
\text { ity to execute annual infrastructure. } \\
\text { At present, the cities do not build at } \\
\text { the initially projected rhythm for the } \\
\text { necessary infrastructure for the SETP; } \\
\text { therefore, the execution does not } \\
\text { coincide with the disbursements of the } \\
\text { Nation and the territorial entity agreed } \\
\text { in the co-financing agreement. } \\
\text { Although transport operators were } \\
\text { transformed under a single company, } \\
\text { they did so based on the permits } \\
\text { issued under Decree } 170 \text { (2001) by } \\
\text { the transport authority; however, it } \\
\text { was necessary to know the number of } \\
\text { vehicles that were actually in opera- } \\
\text { tion by each of the companies, with the } \\
\text { purpose of defining the shareholding of } \\
\text { the unified company. } \\
\text { The infrastructure costs of the Strategic } \\
\text { Systems were calculated based on } \\
\text { conceptual designs. The changing con- } \\
\text { ditions of cities require the updating of } \\
\text { studies that have an impact on the costs } \\
\text { initially calculated. }\end{array}$ \\
\hline
\end{tabular}

fleet. In this sense, it is proposed to the territories to follow the following procedure:

- Characterize the total of trips; this will allow obtaining the percentage of each of the means of transport. The above will be the technical sup- port to establish the proportion of target trips that would be potential users of the SETP.

- Operationally, travel recovery goals must be established, for they have been lost through informal and illegal processes of public transportation, with 
the purpose of including expected demands in the evaluated scenarios, with great emphasis on the strategies of "capturing" the demand to public transport.

- Diagnose the conditions of the fleet with which the collective public transport operation counts: quantity of fleet, capacity and vehicles in effective operation.

- Identify the number of vehicles that have a service time greater than or equal to 15 years, and start with a financial model that allows them to remu-

Table 2. Successes and failures related to the operational component

\begin{tabular}{|c|c|}
\hline & \\
\hline $\begin{array}{l}\text { - The current operation allows } 100 \% \\
\text { coverage of the territory, which is why } \\
\text { the city of Pasto reflects the lower rates of } \\
\text { informality and illegality of the cities that } \\
\text { implement SETP. } \\
\text { - Although the conditions of the workshops } \\
\text { are not the best in all cases, the transport } \\
\text { operator has taken care to consolidate } \\
\text { them and keep them in optimum opera- } \\
\text { tion. } \\
\text { The largest percentage of the current } \\
\text { fleet in the municipality is less than } 15 \\
\text { years old, that is, they have implemented } \\
\text { replacement strategies over time within } \\
\text { the transport companies. } \\
\text { This type of mobility solutions tend to } \\
\text { articulate territorial planning decisions } \\
\text { and are consolidated as structuring axes of } \\
\text { the territory. }\end{array}$ & $\begin{array}{l}\text { - Informal transport has been allowed to } \\
\text { satisfy the population's travel wishes in the } \\
\text { same proportion. } \\
\text { - Although the need for infrastructure for } \\
\text { the optimal operation of the SETP has } \\
\text { been identified, no work prioritization } \\
\text { analysis was carried out according to the } \\
\text { number of passengers transported. } \\
\text { There is not enough technical capac- } \\
\text { ity in the territorial entities that allow } \\
\text { to evaluate the models delivered by the } \\
\text { consultants that develop the conceptual } \\
\text { design and the detailed structure. } \\
\text { The current transporters have begun the } \\
\text { acquisition of a fleet of } 40 \text { passengers, } \\
\text { recommended by the detailed structure. It } \\
\text { is advisable to review the transport model } \\
\text { to make the best decision, which finally } \\
\text { impacts the value of each of the equip- } \\
\text { ment to acquire. }\end{array}$ \\
\hline
\end{tabular}

Table 3. Summary of the operational indicators of the second scenario of modeling

\begin{tabular}{|c|c|c|}
\hline Horizons of Analysis & YEAR 5 & YEAR 10 \\
\hline Approaches & 23,576 & 26,602 \\
\hline Average PIK & 4.49 & 4.72 \\
\hline Minimum Interval & 4 & 15 \\
\hline Maximum Interval & 15 & 383 \\
\hline Fleet Required 33 PAX & 359 & 39 \\
\hline Reserve Fleet (10\%) & 36 & \\
\hline
\end{tabular}




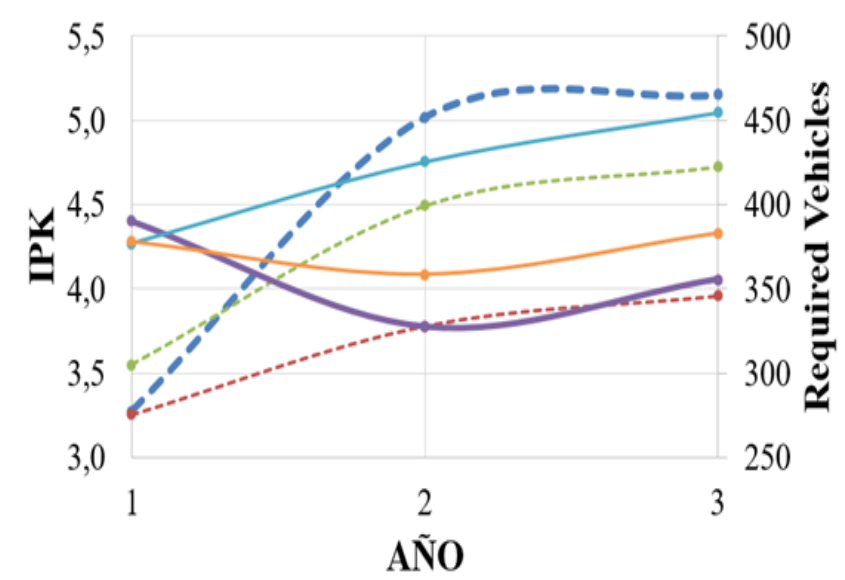

$\rightarrow$ Scenario 1 - Average IPK $\rightarrow$ Scenario 2 - Average IPK

$-\rightarrow$ - Scenario 3 - Average IPK $\rightarrow$ Scenario 1 - Required vehicles

$\rightarrow$ Scenario 2 - Required vehicles $\rightarrow$ Scenario 3 - Required vehicles

Figure 8. Required vehicles vs. PIK - scenarios of modeling.

nerate them and achieve a salvage value for the team.

- According to the conceptual design and the calibrated model, define the capacity of the fleet according to the greatest number of vehicles. This will make it possible to unify the operating conditions and facilitate the equipment and operators in charge of maintenance.

With the information previously presented, the following three modeling scenarios are proposed to the territories that have between 250,000 and 600,000 inhabitants:

First scenario of modeling: This is generated from what was projected by the calibrated model of the detail structure, with the purpose of counting the current situation of the city. In addition, two new scenarios are modeled for 2020 and 2025 with the normal population growth, performing an analysis in terms of boarding, average Passenger Index per Kilometer (PIK), minimum and maximum intervals, fleet required, reserve and total.

Second modeling scenario: Based on the first scenario, the second modeling scenario is constructed from releasing the dispatch intervals and the capacity of the fleet, so that through iterative processes the transport model obtains dispatch intervals and the fleet capacity suggested. As an example and in the case of Pasto, the results obtained for this scenario are presented in Table 3.

Third modeling scenario: This is done based on the results of the second modeling scenario, based on the largest percentage of the current fleet that the transporters of the city of Pasto have (30-passenger buses and interval optimization 3 to 7 minutes). In this sense, for this city, year 0 , it is recommended to use scenario three (3) as part of the pre-operative stage because it has the least number of vehicles required and the highest PIK for the model of full transport. For year 2 of implementation, it is recommended to work with the second scenario, with the purpose of making the decision of the private operator in the acquisition of the vehicular typology that will be adopted for the SETP. For this case, we recommend a typology of between 35 and 40 passengers that does not exceed two typologies due to the facilities in the operation and maintenance of the equipment.

Comparison of modeling scenarios: however, and because the operational stage should be in year 2 (i.e. in the year 2020 for the purposes of the developed model summarized in Figure 8), it is recommended to use the first modeling scenario 1, which is the recommended scenario for the structuring of detail under the parameters described there due to the high PIK and the reduced number of vehicles required since the demand hypotheses are being met over time.

\subsection{Analysis and Proposals of the Image Component}

In order to have diagnosis, analysis, successes, mistakes and finally a formulation of guidelines in terms of image, it became necessary to delve into the concept of " $\mathrm{Z}$ Theory"- in the understanding that the businesses structures should understand the relationship between people who come into direct contact with the buyers of the service in this case, the relationship of the SETP drivers with the clients or passengers transported. A series of guidelines for the development of the brand and strategies for user loyalty are proposed, which considers "fidelity as an attitude that assumes that different customer sensations 
Table 4. Successes and failures related to the image component

\begin{tabular}{|c|c|}
\hline Successes & Failures \\
\hline $\begin{array}{l}\text { - Start of installation of cameras } \\
\text { on board vehicles that control the } \\
\text { number of passengers and provide } \\
\text { security inside the vehicle. } \\
\text { - Approaches to participatory plan- } \\
\text { ning in the election of the elements } \\
\text { of the SETP brand. } \\
\text { - Election of the name of the SETP as } \\
\text { part of the brand according to the } \\
\text { characteristics of the region. } \\
\text { - Implementation of differentiating } \\
\text { strategies in the on-board experi- } \\
\text { ence of the users. } \\
\text { Implementation of strategies to } \\
\text { attract users to the System. }\end{array}$ & $\begin{array}{l}\text { - Poor working conditions of the } \\
\text { drivers of the transport service } \\
\text { operators } \\
\text { - Lack of technological control in } \\
\text { vehicle tracking } \\
\text { - Between low and zero investment in } \\
\text { labor welfare and strategies for the } \\
\text { appropriation of workers } \\
\text { - Internalization of labor formaliza- } \\
\text { tion costs } \\
\text { Although user attraction strategies } \\
\text { were implemented at the time, they } \\
\text { did not turn into loyalty nor sense of } \\
\text { belonging to the System }\end{array}$ \\
\hline
\end{tabular}

create an individual attachment to service” $\underline{\underline{10}}$. The guidelines are proposed based on the strategies implemented by the transportation companies of the city of Pasto, which have recovered demand that at the time migrated to other modes of transport as a passenger or driver of a new vehicle, analyzing in detail the successes and mistakes (Table 4).

Complementing the above and with the purpose of analogously sketching what companies should do, a series of recommendations are made based on the theories of the subject ${ }^{9,11}$.

- The transport companies must train all their employees in elements such as the provision of passenger service and how it is framed in the company in the PNTP, in order to have a critical and proactive look of the provision. In addition, decisions must be made not only from the management of the companies, but also through participatory planning and decision-making processes.

- Conduct a market study to define the salary of drivers and other employees of the company, allowing them to live with dignity in the conditions offered by the city of Pasto, without leaving aside the evaluation of incentives to remain in the transport operator company.

- Transform the institution to achieve the new purposes of the company, defining the processes necessary to reach said transformation, including areas that allow capturing economies of scale and that could have rotation between the functions provided by the transport operator.

- Carry out the five phases at scale developed under the " $\mathrm{Z}$ theory": 1 , Take the lessons learned and successful cases that implement organized transport systems in terms of transport technologies, tire consumption, bodywork type, on-board equipment and other elements of the operation of a SETP; 2, Protect local transporters and small owners, the core of the operation; 3 . Reduce the direct costs of the operation through strategies such as the massive purchase of lubricants, largescale negotiations with suppliers of the brand of 
the team, review of the fuel policy in tariff terms, etc.; 4 . Strive to capture the totality of the demand of users who move in the city of Pasto, without allowing illegality and informality; 5. High specialization in each of the processes associated with the provision of the service.

Accordingly, it is necessary that companies are transformed and that the user feels identified with the transport service. The experiences of other Colombian cities have given positive results for the general users and for the mobilization of passengers. In this sense, it is recommended that companies in the city of Pasto, with the support of co-financing resources of the Managing Entity, develop studies such as $\frac{12}{}$, which allows measuring the personality of the brand evaluated in five dimensions: sincerity (practical, honest, healthy, cheerful); exciting (daring, animated, imaginative, updated); competition (reliable, intelligent, successful); sophisticated (upper class, charming); rudeness (open, resistant). An example of application of personality studies of the brand was carried out in airlines by $\frac{13}{}$.

As for the loyalty strategies that are framed in the criteria mentioned above, it is necessary to allocate resources to serve the user, finding examples where a loyalty program is supported with $1 \%$ of the company's sales. That is to say, if Pasto's passenger transport system plans to mobilize around 123,188 passengers a day at a rate of 0.6 USD, it would be advisable to invest some 16,300 USD per month in order to strengthen the user's service, information, problems, the complaints, the claims and the loyalty. It is recommended to follow the following guidelines, having identified that the evasion of resources not recorded by drivers would be one of the main funds to support them.

- Due to the fact that the SETP plans payment with an electronic card, it is necessary to incentivize its personalization to link the loyalty services.

- Link the public transport card to complementary transport services. That is, the territorial admin- istration is currently carrying out a program of public bicycles and this card should serve for integration with this sustainable mode.

- Within the framework of the projected investment, develop the financial model that allows estimating a number of free trips per passenger after a certain number of promotions registered in the SETP.

- Make business alliances that allow users to diversify the use of the card, in the case of banks with automatic debit in the payment of the ticket. Take up the initiative of material incentives for the use of the transport system, within the framework of a policy of loyalty and not just attraction.

\section{Conclusions}

The main weakness of the institutional component is identified in the fact that the National Government has not defined mechanisms to monitor and control traditional transportation systems. However, a monitoring committee was set up consisting of the MT, DNP, MHCP for the implementation of the new PNTP, and for the first time the Territorial Entities formed an institution which thinks exclusively of the implementation of a SETP, called Managing Entity. It should be invested in the planning pyramid of the framework of business transformation, under the promotion of the brand, the service approach to the user, the correct decision in the vehicle typology, the level of service in the operation. The above would drive the change in the variability of the number of passengers transported, which has been decreasing linearly and with a negative slope for different reasons (social, improvement in national economic indicators, informal transport, transport technology solutions, etc.). These proposed guidelines should be understood as a series of actions, decisions and conditions that seek to increase efficiency in the implementation of SETP.

Although teams of professionals have been created within the National Government to monitor the implementation of the PNTP, these are not enough to provide 
the technical support required by the territorial entities. Strengthening professional teams would increase the total investment of the SETP by just $2 \%$ in the case of the city of Pasto. Including the principles of trust, subtlety, equity, sense of belonging, loyalty and humility for employees related to the provision of the Organized Transportation System, together with the user's loyalty, would allow people who access the SETP to understand that, as a customer today, he has the ability to choose, but he must be attracted to environmentally responsible ways.

It is essential for each of the actors involved in the implementation of SETP to know the organizational structures of the National Government (Ministry of Finance and Public Credit, Ministry of Transportation and National Planning Department), Local Government (Secretary of Mobility and/or Transit and Transport, Managing Entity and Municipality) and the structure of the transporting companies, in the framework of reducing learning curves in the changes of national and territorial administration.

\section{Acknowledgments}

The authors express their sincere thanks to the students belonging to the research groups in Sustainable Mobility and Urban Planning of the National University of Colombia, Sede Manizales.

\section{References}

1. Gomez, C. Policy transfer on urban transport systems: The process adaptation of the Masivo Integrado de Occidente (MIO). Ciencia Politica. 2013; 15:36-66.

2. Suzuki H, Cervero R, Iuchi K. Transforming cities with transit, transit and land-use integration for sustainable urban development. Washington D.C.: The World Bank; 2013. p. 1-233. Crossref.
3. National Planning Department Colombia \& Ministry of Transport. Politica para mejorar el servicio de transporte Público urbano de pasajeros. Archivos De Economía 003339, Departamento Nacional De Planeacion; 2002.

4. Colombia Republic. Decree 3422, por el cual se reglamentan los Sistemas Estrategicos de Transporte Publicos (SETP) de conformidad con la Ley 1151 de 2007. Diario Oficial 47.468 de septiembre 10 de 2009. 2009. http://www.alcaldiabogota. gov.co/sisjur/normas/Norma1.jsp?i=37515.

5. Ministry of Transport. Decree 1079, por medio del cual se expide el Decreto Único Reglamentario del Sector Transporte. Diario Oficial 49.523 de mayo 26 de 2015. Colombia Republic. 2015. http://www.alcaldiabogota.gov. co/sisjur/normas/Norma1.jsp?i=62514

6. Departamento Administrativo Nacional de Estadística - DANE. Proyecciones de población total por sexo y grupos de edad de 0 hasta 80 y más a-os $(2005$ - 2020).2018. https://www.dane.gov.co/index.php/estadisticas-por-tema/ demografia-y-poblacion/proyecciones-de-poblacion

7. Ministry of Finance and Public Credit. 2018. https:// en.wikipedia.org/wiki/Ministry_of_Finance_and_Public_ Credit_(Colombia)

8. De Rus G, Campos J, Nombela G. Economía del transporte. Barcelona: Antoni Bosch S.A. 2003.

9. Ouchi WG. Theory Z: How American business can meet the Japanese Challenge. Reading, Mass.: Addison-Wesley. 1981. p. 269-71.

10. Seto D. La fidelidad del cliente en el ambito de los servicios: Un análisis de la escala intenciones de comportamiento. Investigaciones Europeas de Dirección y Economia de la Empresa. 2003; 9(2):189-204.

11. Lopez J, Maldonado L. Teoría Z. Como pueden las empresas hacer frente al desafío Japones? Mexico D.F. Fondo Educativo Interamericano y Editorial Norma; 1982. p. 1-7.

12. Aaker J. Dimensions of brand personality. Journal of Marketing Research. 1997; 34(3):347-356. Crossref.

13. Schlesinger M. Estudio comparativo entre personalidad de marca ideal vs. Percibida: aplicacion a las compa-ías aereas. Innovar. 2008; 18(31):61-76. 